ROCZNIKI NAUK PRAWNYCH

Tom XXIX, numer $1-2019$

DOI: http://dx.doi.org/10.18290/rnp.2019.29.1-5

ANDRZEJ WRZYSZCZ

HUBERT MIELNIK

\title{
STATUS PRAWNY DZIECKA \\ W NIEMIECKIM USTAWODAWSTWIE \\ W GENERALNYM GUBERNATORSTWIE (1939-1945)
}

\section{WPROWADZENIE}

Generalne Gubernatorstwo dla okupowanych polskich obszarów funkcjonowało oficjalnie od 26 października 1939 r. Od 15 sierpnia 1940 r. zmieniono jego nazwę na Generalne Gubernatorstwo [dalej jako: GG], co miało świadczyć o jego bliższym związku z Rzeszą Niemiecką. Przez cały okres istnienia tego organizmu okupacyjnego funkcje generalnego gubernatora sprawował Hans Frank ${ }^{1}$.

Zasady wydawania nowych przepisów prawnych przez okupanta niemieckiego w GG zostaną omówione niżej. Już teraz trzeba jednak podkreślić, że pierwsze ure-

Dr hab. ANDRZEJ WrZYSZCZ, prof. UMCS - Kierownik Katedry Historii Państwa i Prawa, Instytut Historii i Teorii Państwa i Prawa, Wydział Prawa i Administracji Uniwersytetu Marii Curie-Skłodowskiej w Lublinie, Pl. M.C. Skłodowskiej 5, 20-031 Lublin; e-mail: andrzej.wrzyszcz@poczta.umcs.lublin.pl; https://orcid.org/0000-0002-9824-4251

Mgr Hubert MielniK - asystent w Katedrze Historii Państwa i Prawa, Instytut Historii i Teorii Państwa i Prawa, Wydział Prawa i Administracji Uniwersytetu Marii Curie-Skłodowskiej w Lublinie, Pl. M.C. Skłodowskiej 5, 20-031 Lublin; e-mail: hubert.mielnik@poczta.umcs.lublin.pl; https://orcid.org/0000-0002-6299-742X

${ }^{1} \mathrm{~W}$ dniu 31 lipca 1940 r. Hans Frank wydał dekret (powołując się na upoważnienie udzielone mu przez Adolfa Hitlera), na podstawie którego wprowadzono nazwę Generalne Gubernatorstwo od 15 sierpnia 1940 r. A. WeH, Prawo Generalnego Gubernatorstwa w uktadzie rzeczowym z objaśnieniami i szczegółowym skorowidzem, wyd. 3, Kraków: Institut für detusche Ostarbeit 1941, A 100, Dekret führera i kanclerza Rzeszy Niemieckiej o administracji okupowanych polskich obszarów z 12 października 1939 r.; A 110, Proklamacja generalnego gubernatora z 26 października 1939 r.; A 102, Dekret w sprawie nowych uregulowań organizacyjnych w Generalnym Gubernatorstwie z 31 lipca 1940 r.; D. SchENK, Hans Frank. Biografia generalnego gubernatora, Kraków: Wydawnictwo Znak 2009, passim; K. GRÜnBERG, B. OTRĘBA, Hans Frank na Wawelu, Włocławek: Wyższa Szkoła Humanistyczno-Ekonomiczna we Włocławku 2001, passim. 
gulowania odnoszące się do młodocianych wprowadzono w okresie zarządu wojskowego Wehrmachtu jeszcze w trakcie działań wojennych. Zarząd wojskowy trwał prawie dwa miesiące od 1 września do 25 października 1939 r. Kompetencje do wydawania przepisów prawnych w tym okresie posiadał niemiecki naczelny dowódca wojsk lądowych, a od 16 października 1939 r. także naczelny szef administracji. Ustanawiane przez nich akty normatywne publikowane były w Dzienniku rozporządzeń dla obszarów okupowanych w Polsce (w dwóch równoległych wersjach językowych: niemieckiej i polskiej) ${ }^{2}$.

Interesujący nas akt prawny wydał naczelny dowódca wojsk lądowych w dniu 10 września 1939 r. Było to rozporządzenie o zawyrokowaniu czynów młodocianych. Na jego podstawie młodociani mieli być karani jak dorośli przestępcy (bez względu na ich wiek), jeżeli pod względem rozwoju fizycznego dorównywali osiemnastoletniej osobie ${ }^{3}$.

Po utworzeniu Generalnego Gubernatorstwa Hans Frank uznał przepisy wprowadzone w okresie zarządu wojskowego za obowiązujące, o ile nie stały się bezprzedmiotowe, albo nie zostały wyraźnie uchylone ${ }^{4}$. Wedle naszej wiedzy przepisy rozporządzenia z 10 września 1939 r. odnoszące się do młodocianych stosowane były na terenie GG.

Kompetencje do stanowienia prawa w Generalnym Gubernatorstwie przez okupacyjne władze niemieckie wynikały z dekretu Hitlera z 12 października $1939 \mathrm{r}$. Uprawnienia ustawodawcze w stosunku do GG uzyskała Rada Ministrów do Obrony Rzeszy oraz pełnomocnik dla planu czteroletniego. W praktyce w ciągu kilku lat okupacji akty normatywne obowiązujące w Generalnym Gubernatorstwie wydawały też inne centralne organy Rzeszy i sam Hitler. Akty te były jednak bardzo nieliczne i nie odnosiły się bezpośrednio do statusu prawnego dzieci w $\mathrm{GG}^{5}$. Najważniejszym podmiotem posiadającym kompetencje ustawodawcze w GG był general-

\footnotetext{
${ }^{2}$ A. WRZYSZCZ, Okupacyjne sadownictwo niemieckie w Generalnym Gubernatorstwie 19391945. Organizacja i funkcjonowanie, Lublin: Wydawnictwo Uniwersytetu Marii Curie-Skłodowskiej 2008, s. 57.

${ }^{3}$ Dziennik rozporządzeń dla obszarów okupowanych w Polsce, nr 3, s. 7. Podobne rozporządzenie wydały także władze Rzeszy. Rozporządzenie o ochronie przeciwko nieletnim ciężkim przestępcom z 4 października 1939 r. (Verordnung zum Schutz gegen jugendlische Schwerverbrecher, Reichsgesetzblatt [dalej cyt.: RGBl] 1939, cz. I, nr 199, s. 2000) upoważniało prokuratora do wnoszenia aktów oskarżenia przeciwko nieletnim w wieku 16-18 lat, jeżeli byli dobrze rozwinięci fizycznie i psychicznie oraz jeżeli wymagała tego „ochrona narodu niemieckiego”. Na jego mocy nieletnich skazywano na kary przewidziane dla dorosłych.

4 WeH, Prawo Generalnego, A 120, Pierwsze rozporządzenie o odbudowie administracji okupowanych polskich obszarów z 26 października 1939 r., paragraf 8, przypis 25.

${ }^{5}$ Tamże, A 100, paragraf 5; WRZYSZCZ, Okupacyjne sądownictwo, s. 345-349.
} 
ny gubernator Hans Frank. Realizował je w różnych formach: proklamacjach, które miały charakter propagandowy, dekretach (regulowały zagadnienia ustrojowe) i przede wszystkim najliczniejszych rozporządzeniach stanowiących odpowiednik ustaw funkcjonujących w ustrojach demokratycznych (oczywiście tylko w zakresie ich merytorycznej treści, a nie przymiotu praworządności). Obok generalnego gubernatora samodzielne uprawnienia ustawodawcze posiadał wyższy dowódca SS i policji. Przepisy wykonawcze (zarządzenia, rozporządzenia wykonawcze, postanowienia wykonawcze, ordynacje taryfowe, obwieszczenia) do aktów generalnego gubernatora wydawały różne organy niemieckiej administracji centralnej Generalnego Gubernatorstwa ${ }^{6}$.

Publikator urzędowy, w którym drukowano akty normatywne tworzone w GG ukazywał się w latach 1939-1944 i jak na taki krótki okres często zmieniał nazwę i strukturę wewnętrzną. Pierwotny tytuł to „Dziennik Rozporządzeń Generalnego Gubernatora dla okupowanych polskich obszarów”, od 1 września 1940 r. zmieniono jego nazwę na „Dziennik Rozporządzeń dla Generalnego Gubernatorstwa”. Przez jeden rok (1940) publikator podzielony był na dwie części. W części I zamieszczano akty wyższego rzędu (proklamacje, dekrety i rozporządzenia generalnego gubernatora), w części II akty niższego rzędu. Początkowo dziennik publikowano w podwójnej wersji językowej (na jednej szpalcie tekst w języku niemieckim i obok w języku polskim). Po przyłączeniu do GG dystryktu Galicja przez kilka miesięcy drukowano oddzielną ukraińską wersję tego publikatora (1 sierpnia - 31 grudnia 1941 r.), w latach 1942-1943 dwie wersje dziennika: niemiecko-polską i niemiecko-ukraińską. Od 1 stycznia 1944 r. ze względów oszczędnościowych zdecydowano o wydawaniu trzech oddzielnych edycji: niemieckiej, polskiej i ukraińskiej ${ }^{7}$.

Na łamach urzędowego publikatora odnajdujemy akty normatywne odnoszące się do statusu prawnego dzieci w Generalnym Gubernatorstwie. Jak wyżej wspomniano, odnoszą się one do sfery prawa karnego, ale także prawa prywatnego i przede wszystkim prawa administracyjnego oraz prawa pracy.

\footnotetext{
${ }^{6}$ G.O. Grassmann, Die deutsche Besatzungsgesetzgebung während des 2. Weltkrieges, Studien des Instituts für Besatzungsfragen in Tübingen zu den deutschen Besetzungen im 2. Weltkrieg, $\mathrm{Nr}$ 14, Tübingen: Institut für Besatzungsfragen 1958, s. 43-45; A. WRZYszCZ, Hierarchia aktów prawnych wprowadzonych przez okupanta niemieckiego w Generalnym Gubernatorstwie w latach 19391945, „Studia Iuridica Lublinensia” 22 (2014), s. 697-699.

${ }^{7}$ A. WrZYszcZ, Ustawodawstwo okupacyjne dla dystryktu Galicja 1941-1944, [w:] Studia z historii państwa, prawa i idei, prace dedykowane Profesorowi Janowi Malarczykowi, red. A. Korobowicz, H. Olszewski, Lublin: Wydawnictwo Uniwersytetu Marii Curie-Skłodowskiej 1997, s. 487489; TENŻE, Okupacyjne sądownictwo, s. 357-360.
} 


\section{OKREŚLANIE PRZYNALEŻNOŚCI NARODOWEJ I RASOWEJ DZIECI}

Odrębny status prawny poszczególnych grup narodowościowych zamieszkujących GG wpływał na wiele stosunków cywilnoprawnych. Dotyczyło to także kwestii związanych z pozycją prawną dziecka. Istotne znaczenie w tym kontekście miało przypisanie statusu narodowego albo rasowego dzieciom pochodzącym ze związków mieszanych. Przedmiotem regulacji przepisów wydawanych w GG było z jednej strony to, które dzieci uznawać za żydowskie, z drugiej natomiast, które miały mieć status osób narodowości lub pochodzenia niemieckiego.

\subsection{DZIECI ŻYDOWSKIE}

Za Żydów uznawano dzieci urodzone po 31 maja 1941 r., jeżeli pochodziły ze związków pozamałżeńskich, a jeden z rodziców był Żydem oraz dwoje z dziadków było „pod względem rasowym pochodzenia czysto żydowskiego” ${ }^{\text {. }}$. De facto więc dzieci urodzone poza małżeństwem i mające jednego z rodziców Żyda, były traktowane jako Żydzi. Na marginesie wspomnieć należy o obowiązku oznaczania Żydów. Opaski w postaci białego paska o szerokości co najmniej $10 \mathrm{~cm}$ z Gwiazdą Dawida musieli nosić, od 1 grudnia 1939 r., wszyscy Żydzi mający ukończone 10 lat'. Wprowadzona granica wieku nakazywała więc nosić opisaną opaskę wszystkim dzieciom, które mogły sobie poradzić bez podstawowej opieki, a więc niezbędne było ich stosowne oznaczenie.

\subsection{DZIECI NIEMIECKIE}

Na początku wskazać należy, że w Generalnym Gubernatorstwie funkcjonowały trzy kategorie „Niemców”: Reichsdeutsche (osoby posiadające obywatelstwo niemieckie); Volksdeutsche (osoby narodowości niemieckiej); Deutschstämmige (osoby pochodzenia niemieckiego). Od 1941 r., kiedy wprowadzono kategorię osób pochodzenia niemieckiego, istniała następująca hierarchia „niemieckości” w GG, licząc od najniższego stopnia: Deutschstämmiger - Volksdeutscher-Reichsdeutscher ${ }^{10}$.

\footnotetext{
${ }^{8}$ Rozporządzenie o definicji pojęcia „Żyd” w Generalnym Gubernatorstwie z 24 lipca 1940 r., Dziennik Rozporządzeń Generalnego Gubernatora dla okupowanych polskich obszarów [dalej cyt.: Dz. RGGOP], cz. I, nr 48, s. 231, § 2 ust. 1 pkt c.

${ }^{9}$ Rozporządzenie o oznaczeniu Żydów i Żydówek w Generalnym Gubernatorstwie z 23 listopada 1939 r., Dz. RGGOP, nr 8, s. 61, § 1.

${ }^{10}$ Więcej w: A. KLAFKOwsKi, Okupacja niemiecka w Polsce w świetle prawa narodów, Poznań: Wydawnictwo Instytutu Zachodniego 1946, s. 97.
} 
W 1942 r. na mocy piątego postanowienia wykonawczego do rozporządzenia o sądownictwie niemieckim uregulowano ${ }^{11}$, że dla spraw ze stosunku prawnego między rodzicami a dzieckiem ślubnym, stosunku prawnego między dzieckiem nieślubnym a jego matką, ustalenia i uznania ojcostwa dziecka pozamałżeńskiego, jak również w sprawach obowiązku ojca utrzymania nieślubnego dziecka, właściwe było prawo obowiązujące w Rzeszy i sprawa powinna być rozpatrywana przez sądownictwo niemieckie, jeżeli jeden z rodziców był obywatelem niemieckim lub osobą narodowości niemieckiej ${ }^{12}$. Po wydaniu tego postanowienia wykonawczego Kurt Wille, kierownik Głównego Wydziału Sprawiedliwości w Rządzie Generalnego Gubernatorstwa wystosował do dystryktowych wydziałów spraiedliwości okólnik, w którym twierdził, że dzięki temu możliwe będzie odbieranie dzieci matkom nieniemieckim. Było to narzucenie sądom niemieckim określonego sposobu interpretacji i postępowania ${ }^{13}$. Willemu chodziło o stosowanie $§ 1666$ niemieckiego kodeksu cywilnego, który pozwalał na pozbawienie nieniemieckiej matki pieczy nad dzieckiem i przeniesienie tej pieczy na osoby lub urzędy upoważnione do podejmowania kroków niezbędnych do wychowania dziecka w duchu niemieckim. W okólniku został nawet podany sposób uzasadniania tego typu decyzji, nieniemieckie matki wzbraniające się przed oddaniem dziecka pochodzącego od niemieckiego ojca do domu dziecka, miały w ten sposób nadużywać opieki nad dzieckiem. Silnie podkreślona została także konieczność wychowywania dzieci pochodzących od niemieckich ojców w niemieckim środowisku i wpajania im niemieckich tradycji narodowych ${ }^{14}$.

\footnotetext{
${ }^{11}$ Rozporządzenie o sądownictwie niemieckim w Generalnym Gubernatorstwie z 19 lutego 1940 r., Dz. RGGOP, cz. I, nr 13, s. 57.

${ }^{12}$ Piąte postanowienie wykonawcze do rozporządzenia z 19 lutego 1940 r. o sądownictwie niemieckim w GG z 26 czerwca 1942 r., Dziennik Rozporządzeń dla Generalnego Gubernatorstwa [dalej cyt.: Dz. RGG], nr 58, s. 361, jedyny paragraf.

${ }^{13}$ Sądy niemieckie stosowały ten sposób interpretacji. Sąd niemiecki w Lublinie w wyroku z 9 września 1942 r. w sprawie powierzenia opieki nad dzieckiem, którego ojciec był Polakiem, a matką Niemką, uzasadniał: „Ojciec nie może się powoływać na zawartą przed rozwodem umowę, na podstawie której dziecko ma pozostawać u niego na wypadek rozwodu. $Z$ tej umowy wynika mianowicie, że ojciec zamierzał zabezpieczyć dziecku polskie wychowanie. [...] Wychowanie dziecka u ojca nie jest dostatecznie zapewnione, gdyż nawet nie posyłał dziecka do niemieckiej szkoły. Dlatego należy obawiać się, że dziecko będzie wychowywane przez ojca w polskim duchu, jeśli on nawet pozwalał uczyć ją języka niemieckiego. W tych okolicznościach musi się uznać zawartą między rodzicami umowę o zrzeczenie się przez matkę prawa opieki za pozbawioną skutków prawnych. Co więcej, najlepiej służyć będzie dobru dziecka, jeśli pójdzie ono do matki i w ten sposób otrzyma niemieckie wychowanie. Matka dziecka będzie wychowywać je w niemieckim duchu i zachowa je dla narodu niemieckiego [...]". Cyt. za: J. WNUK, Polskie dzieci oskarżają, Lublin: Wydawnictwo Lubelskie 1975, s. 50.

${ }^{14}$ Archiwum Państwowe w Lublinie [dalej cyt.: APL], Urząd Okręgu Lubelskiego [dalej cyt.: UOL], sygn. 914, k. 206.
} 
W świetle ustawodawstwa GG dzieci poniżej 15 roku życia, były traktowane jako osoby pochodzenia niemieckiego, jeżeli co najmniej jeden z rodziców posiadał legitymację dla osób pochodzenia niemieckiego. Osoby z tej kategorii podlegały w sprawach z zakresu prawa osobowego i rodzinnego sądownictwu niemieckiemu, prawem właściwym wobec nich w tym zakresie było prawo obowiązujące w Rzeszy ${ }^{15}$.

\section{ODPOWIEDZIALNOŚĆ KARNA DZIECI}

Problematykę statusu prawnego dziecka na gruncie prawa karnego rozpatrywać można na dwóch płaszczyznach: dziecka (nieletniego) jako sprawcy czynu karalnego oraz dziecka jako przedmiotu ochrony w prawie karnym (np. rozdział XXXI kodeksu karnego z 1932 r. - Przestępstwa przeciwko opiece i nadzorowi). W ustawodawstwie niemieckim w GG próżno szukać norm odnoszących się do ochrony praw dziecka. Większość z wprowadzonych przepisów karnych służyć miało realizacji polityki nazistowskiej w GG, dlatego też w dużym zakresie penalizowano, oprócz wszelkich czynów sprzeciwiających się władzom okupacyjnym i narodowi niemieckiemu, prawie wszystkie obszary życia gospodarczego. W obszarze irrelewantnym, z punktu widzenia nazistowskiej polityki, stosowano prawo przedwojenne, polskie lub niemieckie, w zależności od tego, który sąd uznany został przez niemiecką władzę oskarżenia (prokuraturę) za właściwy do rozpatrzenia sprawy.

Pewne modyfikacje zostały jednak wprowadzone w obszarze odpowiedzialności karnej nieletnich. W zakresie określenia granicy wieku nieletnich, od której ponosili oni odpowiedzialność karną, oprócz omówionej regulacji z okresu zarządu wojskowego, prawo GG nie wprowadzało odrębnych uregulowań, pozostawiając te kwestie odpowiednim przepisom części ogólnej polskiego kodeksu karnego z 1932 r. $^{16}$ oraz niemieckiego kodeksu karnego z 1871 r. Odrębnie wyglądała kwestia odpowiedzialności w postępowaniach przed policyjnymi sądami doraźnymi. Tryb postępowania przed tymi organami został uregulowany w rozporzą-

\footnotetext{
${ }^{15}$ Rozporządzenie o prawie obowiązującym osoby pochodzenia niemieckiego z 30 listopada 1942 r., Dz. RGG, nr 106, s. 739-740, §§ 1-3. O prawie rodzinnym obowiązującym w GG zob.: A. WrzyszCZ, K. DĄ̇RowsKi, Das Familienrecht im Generalgouvernement, [w:] Judiciary and Society between Privacy and Publicity. $8^{\text {th }}$ Conference on Legal History in the Baltic Sea Area, $3^{\text {rd }}$ $6^{\text {th }}$ September 2015, red. D. Janicka, Torun: Wydawnictwo Naukowe Uniwersytetu Mikołaja Kopernika 2016, s. 141-162.

${ }^{16}$ Rozporządzenie Prezydenta Rzeczypospolitej z dnia 11 lipca 1932 r. - Kodeks karny, Dz. U. Nr 60, poz. 571.
} 
dzeniu celem zwalczaniu czynów gwałtu w Generalnym Gubernatorstwie, jednak w żadnym z przepisów nie zakreślono wiekowej granicy odpowiedzialności ${ }^{17}$. Rozporządzenie w omawianym zakresie nie odwoływało się również do żadnego innego aktu prawnego. Problematyki tej nie poruszało także rozporządzenie wyższego dowódcy SS i policji w sprawie zakresu karalności sprawcy, który wykazał czynny żal ${ }^{18}$. Z punktu widzenia czysto prawnego możliwe było więc stosowanie przez policyjne sądy doraźne kary śmierci, przewidzianej $\mathrm{w}$ wielu przepisach wprowadzonych w GG, niezależnie od wieku domniemanego „sprawcy” (pojęcie używane przez rozporządzenie celem zwalczania czynów gwałtu). Działalność policyjnych sądów doraźnych trudno jest utożsamiać ze sprawowaniem wymiaru sprawiedliwości, jednak ich struktura i podstawowe zasady działalności regulowane były przepisami ,prawa”. Brak podstawowych gwarancji względem dziecka jest dobitnym przykładem dla uznania prawa GG za „ustawowe bezprawie”.

Obok określenia wieku odpowiedzialności istotne znaczenie dla statusu prawnego dzieci mają kwestie ich resocjalizacji i stosowania różnego rodzaju środków wychowawczych obok lub zamiast kar. W tym zakresie powstawały jednak wątpliwości prawne. Wynikały one $\mathrm{z}$ faktu, że w rozporządzeniu o sądownictwie polskim z 19 lutego 1940 r. $^{19}$ zakazano stosowania warunkowego zawieszenia kar wolnościowych, grzywien oraz innych ułaskawień (§ 3). W sierpniu 1940 r. Sąd Apelacyjny w Lublinie wystosował zapytanie do Wydziału Sprawiedliwości w Urzędzie Szefa Dystryktu w Lublinie o stosowanie art. 73 kodeksu karnego z 1932 r. ${ }^{20}$ w związku z § 3 rozporządzenia o sądownictwie polskim. W odpowiedzi Wydział Sprawiedliwości, powołując się na centralne organy GG, uznał, że umieszczenie nieletniego w zakładzie poprawczym na mocy art. 70 kodeku karnego z 1932 r. ${ }^{21}$ stanowiło, nie środek wychowawczy, ponieważ środki wychowawcze zostały wyczerpująco wyliczone w art. 69 § 2 kodeksu karnego z 1932 r., lecz środek zabezpieczający. Uznano więc za niemożliwe stosowanie art. 73 kodeksu karnego z 1932 r. i wypadki w których pojawiała się możliwość jego zastosowania zaliczono do sytuacji zasto-

\footnotetext{
${ }^{17}$ Rozporządzenie celem zwalczania czynów gwałtu w Generalnym Gubernatorstwie z 31 października 1939 r., Dz. RGGOP, nr 2, s. 10.

${ }^{18}$ WrzYsZCZ, Okupacyjne sądownictwo, s. 66.

${ }^{19}$ Rozporządzenie o sądownictwie polskim w Generalnym Gubernatorstwie z 19 lutego 1940 r., Dz. RGGOP, cz. I, nr 13, s. 64.

${ }^{20}$ Art. $73 \S 1$. Nieletniemu, który popełnił z rozeznaniem czyn zabroniony pod groźbą kary, a nie zagrożony karą śmierci lub dożywotniego więzienia, sąd mocen jest, jeżeli to uzna za celowe, zawiesić umieszczenie w zakładzie poprawczym tytułem próby na czas od roku do 3 lat.

${ }^{21}$ Art. 70. Nieletniego, który po ukończeniu 13 lat, a przed ukończeniem 17 lat, popełnił z rozeznaniem czyn zabroniony pod groźbą kary, sąd skazuje na umieszczenie w zakładzie poprawczym.
} 
sowania prawa łaski, określanego przez inne przepisy okupacyjne ${ }^{22}$. Sytuacje zawieszenia wobec nieletniego umieszczenia w zakładzie poprawczym, przewidziane przez polski kodeks karny z 1932 r., traktowane były w świetle powyższego jako prawo łaski wymagające zezwolenia odpowiednich władz niemieckich (Wydziału Sprawiedliwości w Urzędzie Szefa Dystryktu) ${ }^{23}$.

W GG nieletni polscy mężczyźni skazani na karę więzienia albo umieszczenie w zakładzie poprawczym odbywali karę w zakładzie karnym dla młodocianych w Studzieńcu (Jugendstrafanswalt) ${ }^{24}$. W Studzieńcu nie byli umieszczani Żydzi, recydywiści (kierowani do zakładów dla dorosłych) oraz chorzy umysłowo i kalecy. Dziewczęta do 17 roku życia były umieszczane w Zakładzie Poprawczym dla Dziewcząt w Warszawie przy ul. Żytniej (Besserungsanstalt für Mädchen). W późniejszym okresie utworzono także Zakład Wychowawczy dla Dziewcząt w Puszczy Mariańskiej (Erziehungsanstalt). Młodocianych Niemców oraz volksdeutschów do 20 roku życia umieszczano w Deutsche Strafanstalt Krakau. W ośrodku tym w 1940 r. uruchomiono oddział dla młodocianych skazanych narodowości polskiej w wieku 17-20 lat z dystryktu krakowskiego oraz chorych umysłowo i kalek do 17 roku życia. Młodociani w wieku 17-20 lat skazani na karę ciężkiego więzienia odbywali karę w Nowym Wiśniczu (mężczyźni) oraz w Tarnowie (kobiety) ${ }^{25}$.

\section{KWESTIA LEGALIZACJI ABORCJI W GENERALNYM GUBERNATORSTWIE}

Wspomnieć należy również o problematyce ewentualnej legalizacji aborcji na terytorium Generalnego Gubernatorstwa. W opinii publicznej panuje powszechne przekonanie, że na terenach okupowanych przez niemieckich nazistów zostało za-

\footnotetext{
${ }^{22}$ APL, SO w Lublinie, sygn. 3/14, k. 304. Pismo Wydziału Sprawiedliwości w Urzędzie Szefa Dystryktu w Lublinie do Kierownika Sądu Apelacyjnego w Lublinie z 7 października $1940 \mathrm{r}$.

${ }^{23}$ Więcej na ten temat: A. WrZYSZCZ, Uwagi o prawie taski w Generalnym Gubernatorstwie (1939-1945). Podstawy normatywne stosowania prawa łaski w GG, „Studia z Dziejów Państwa i Prawa Polskiego" t. IX (2006), cz. 2, s. 445-452.

${ }^{24}$ Faktycznie nieletni umieszczani byli także w innych więzieniach w GG. Dla przykładu w więzieniu na zamku w Lublinie w czasie jednego z badań przeprowadzonych przez Radę Główną Opiekuńczą na 784 więźniów, 106 osób było w wieku 14-18 lat, tj. ok 13,4\%. Za: A. GAŁAN, Martyrologia dzieci i młodzieży w więzieniu na zamku $w$ Lublinie, [w:] Dzieci i młodzież $w$ latach drugiej wojny światowej, red. Cz. Pilichowski, Warszawa: Państwowe Wydawnictwo Naukowe 1982, s. 261.

${ }^{25}$ J. ADAMSKA, Organizowanie więzień sadowych na terenie Generalnego Gubernatorstwa, „Zeszyty Majdanka” t. XII (1987), s. 15-16.
} 
legalizowane usuwanie ciąży u kobiet narodowości polskiej ${ }^{26}$. Twierdzenia te mają swoją podstawę w wydanym 9 marca 1943 r. rozporządzeniu o ochronie małżeństwa, rodziny i macierzyństwa podpisanym przez H. Göringa, przewodniczącego Rady Ministerialnej do spraw Obrony Rzeszy ${ }^{27}$. Rozporządzeniem tym wprowadzono przestępstwo dokonania aborcji, definiowanej jako „zabójstwo owocu życia” (§ 5). Problematyczne jest jednak po pierwsze obowiązywanie tego aktu prawnego względem osób o konkretnej narodowości, po drugie jego obowiązywanie miejscowe. W przepisach końcowych upoważniono Ministra Sprawiedliwości Rzeszy do wydania zarządzenia w którym określi, że przestępstwa wprowadzone tym rozporządzeniem nie będą miały zastosowanie wobec osób nie mających niemieckiego obywatelstwa albo niemieckiej narodowości $(\S 8)^{28}$. Wyraźnie więc upoważniono centralne władze Rzeszy do podjęcia decyzji o nieobowiązywaniu zakazu aborcji względem kobiet nie mających narodowości albo obywatelstwa niemieckiego ${ }^{29}$. Drugi problem dotyczy kwestii obowiązywania miejscowego rozporządzenia. Wyraźnie wskazano, że obowiązuje ono także na ,przyłączonych terenach wschod-

\footnotetext{
${ }^{26}$ M.in.: https://histmag.org/Co-z-ta-aborcja-w-III-Rzeszy-7183 [dostęp: 16.03.2018]; https://no wahistoria.interia.pl/kartka-z-kalendarza/news-9-marca-1943-r-hitler-wprowadza-aborcje-na-terenachpolski,nId,2159191 [dostęp: 16.03.2018]. Pierwotnym źródłem tych twierdzeń jest artykuł: J. HunT, Out of Respect for Life: Nazi Abortion Policy in the Eastern Occupied Territories, ,Journal of Genocide Research" 1 (1999), z. 3, s. 379-385.

${ }^{27}$ Verordnung zum Schutz von Ehe, Familie und Mutterschaft vom 9. März 1943, RGBl cz. I, nr 27, s. 140-141.

${ }^{28}$ Przepis ten zawiera zastrzeżenie, że przedmiotowe zarządzenie może zostać wydane w drodze przewidzianej dla dekretu. Najprawdopodobniej oznacza to, że zarządzenie takie nie było publikowane w Reichsgezetblatt, miało jednak charakter generalny, a nie jednostkowy. Z przeprowadzonej analizy wynika, że w roczniku 1943 i 1944 nie został opublikowany żaden akt prawny w Reichsgezetblatt na mocy tej delegacji. M. Sierocińska wskazuje, że ,[...] 9 marca 1943 roku uchyleniem przez Ministra Sprawiedliwości Rzeszy karalności spędzania płodu, jeśli dotyczyło to zabiegu dokonanego u «robotnic wschodnich»" - a więc zarządzenie to miało zostać wydane w dniu opublikowania rozporządzenia. M. SIEROCIŃSKA, Eksterminacja „,niewartościowych rasowo” dzieci polskich robotnic przymusowych na terenie III Rzeszy w świetle postępowań prowadzonych przez Oddziatowa Komisję Ścigania Zbrodni przeciwko Narodowi Polskiemu w Poznaniu, [w:] https://ipn.gov.pl/pl/aktualnosci/587,Ekstermina cja-niewartosciowych-rasowo-dzieci-polskich-robotnic-przymusowych-na-t.html [dostęp: 17.03.2018].

${ }^{29}$ Radca ministerialny Tietzsch z Ministerstwa Sprawiedliwości Rzeszy tak tłumaczył wprowadzenie tych regulacji: „Dekret ma na celu ochronę niemieckiej rodziny i niemieckiej matki. Za granicą w wielu przypadkach obowiązują regulacje mniej surowe, a czasami w ogóle nie ma żadnej regulacji. Niesprawiedliwe byłoby więc osądzanie osób z zagranicy w tego typu sprawach karnych $\mathrm{z}$ tą samą surowością co Niemców. Dlatego też rozporządzenie upoważnia Ministra Sprawiedliwości Rzeszy do wydania przepisów wykonawczych, które wskazywałyby, że przepisy rozporządzenia nie mają zastosowania do osób, które nie mają niemieckiego obywatelstwa albo niemieckiej narodowości. Właściwe przepisy są przygotowywane”. Wypis z Deutsche Justiz, [w:] Trials of War Crminials before the Nuernberg Military Tribunals. „The Einsatzgruppen case”; „The RuSHA case”, t. IV, Waszyngton 1949, s. 1095-1096.
} 
nich"30. Jest to kwestia o tyle istotna dla postawionego problemu, że w ustawodawstwie Rzeszy termin ten oznaczał dwa okręgi Rzeszy, Gdańsk-Prusy Zachodnie (Reichsgau Danzig-Westpreußen) oraz Kraj Warty (Reichsgau Wartheland), a więc tereny zaanektowane przez Rzeszę w 1939 r. Nie budzi więc wątpliwości fakt, że na polskich terenach włączonych do Rzeszy oraz na terytorium całej Rzeszy, nie penalizowano usunięcia ciąży u kobiet, które nie posiadały niemieckiego obywatelstwa albo niemieckiej narodowości ${ }^{31}$. Inaczej wygląda kwestia obowiązywania tego rozporządzenia na terytorium Generalnego Gubernatorstwa. Problematyka obowiązywania w Generalnym Gubernatorstwie prawa ustanowionego przez władze Rzeszy, które nie miało zastrzeżenia o obowiązywaniu na terytorium GG, ma charakter złożony i niejednoznaczny do oceny ${ }^{32}$. Władze centralne resortu sprawiedliwości GG wydawały okólniki oraz interpretacje, które wskazywały na akty normatywne Rzeszy obowiązujące w GG $^{33}$. Dla przykładu Kurt Wille, kierownik Głównego Wydziału Sprawiedliwości GG w okólniku z 28 marca 1944 r. informował, że nie każde rozporządzenie policyjne z Rzeszy obowiązywało automatycznie w GG i w każdym konkretnym wypadku należało te kwestie indywidualnie rozpatrzeć ${ }^{34}$. Co jednak ważne, sądy niemieckie w GG oraz sądy specjalne stosowały niemieckie prawo karne (materialne) ${ }^{35}$. W zakresie karalności czynów przewidzianych przez rozporządzenie o ochronie małżeństwa, rodziny i macierzyństwa z 9 marca 1943 r. uznać można, że mogło ono być stosowane przez okupacyjne sądownictwo niemieckie w Generalnym Gubernatorstwie. Dotyczyło to wyłącznie kwestii penalizacji usuwania ciąży u Niemek ${ }^{36}$. Odmiennie wygląda

\footnotetext{
${ }^{30} \mathrm{~W}$ oryginale eingegliederten Ostgebieten.

${ }^{31}$ Problem dotyczył przede wszystkim przymusowych robotnic z Polski i Rosji. Dochodziło do przymuszania kobiet do dokonywania aborcji, co miało służyć utrzymaniu statusu kobiet jako robotnic przymusowych, nie przerywanego przez okres ciąży, w szerszym znaczeniu zaś redukcję populacji narodów wschodniej Europy. Trials of War Crminials before the Nuernberg Military Tribunals. „The RuSHA case”; „The Pohl case”, t. V, Waszyngton 1949, s. 112.

${ }^{32}$ Więcej na ten temat: D. MAJER, Narodowo obcy w Trzeciej Rzeszy. Przyczynek do narodowosocjalistycznego ustawodawstwa i praktyki prawniczej $w$ administracji $i$ wymiarze sprawiedliwości ze szczególnym uwzględnieniem ziem wcielonych do Rzeszy i Generalnego Gubernatorstwa, Warszawa: Wydawnictwo Prawnicze 1989, s. 343; WrzYszcz, Okupacyjne sadownictwo, s. 382-384.

${ }^{33}$ APL, UOL, sygn. 914, k. 334-339. Okólnik kierownika GWS z 22 lipca 1943 r. Okólnik ten nie zawiera żadnych informacji na temat obowiązywania przedmiotowego rozporządzenia.

${ }^{34}$ Tamże, k. 351.

${ }^{35}$ Rozporządzenie o sądach specjalnych w Generalnym Gubernatorstwie z 15 listopada 1939 r., Dz. RGGOP, nr 6, s. 34, § 3; rozporządzenie o sądownictwie niemieckim w Generalnym Gubernatorstwie z 19 lutego 1940 r., Dz. RGGOP, cz. I, nr 13,s. 59, § 8.

${ }^{36} \mathrm{~W}$ Generalnym Gubernatorstwie głośna była sprawa polskiego lekarza dra Zygmunta Wałczyńskiego, który wykonał zabieg aborcji niemieckiej urzędniczce. Został on skazany przez Sąd Specjalny w Krakowie na 2 lata więzienia. Pod naciskiem kierownika Instytutu Medycyny Sądowej
} 
natomiast obowiązywanie potencjalnego zarządzenia wyłączającego spod penalizacji usuwanie ciąży u nie-Niemek i ewentualne stosowanie go przez sądy polskie (nieniemieckie) w GG ${ }^{37}$. Pamiętać należy jednak, że w sprawach karnych o właściwości sądu, tego czy konkretna sprawa miała zostać rozpatrzona przez sąd niemiecki albo polski (nieniemiecki) decydowała niemiecka prokuratura (władza oskarżenia) $^{38}$. Możliwe było więc przekazywanie spraw dotyczących aborcji nieNiemek sądownictwu niemieckiemu, orzekającemu na podstawie niemieckiego prawa, co wiązałoby się z umarzaniem takich spraw i faktyczną legalizacją usuwania ciąży. Taką interpretację potwierdzają akta procesu norymberskiego, w akcie oskarżenia tak zwanej sprawy RuSHA (United States of America vs. Ulrich Greifelt et. al) znalazł się zarzut: „Aborcja polskich kobiet w Generalnym Gubernatorstwie była propagowana poprzez wyłączanie spraw dotyczących aborcji spod jurysdykcji sądów polskich" ${ }^{39}$. Powyższe potwierdza więc tezę, że usuwanie ciąży nie było penalizowane w Generalnym Gubernatorstwie, nie udało się jednak ustalić dokładnie na jakiej podstawie prawnej i w jakim okresie. Problematyka ta wymaga jeszcze poszerzonych badań archiwalnych, głównie zaś akt sądowych tego typu spraw. Pamiętać należy jednak, że powyższe refleksje dotyczą wyłącznie sfery czysto normatywnej i nie przesądzają o stanie faktycznym w zakresie usuwania ciąży w Generalnym Gubernatorstwie.

\footnotetext{
i Kryminalistyki Becka oraz dowódcy SS i policji Krügera zastosowano przewidziany przez przepisy obowiązujące w GG sprzeciw nadzwyczajny. W ponownym procesie Wyższy Sąd Niemiecki w Krakowie skazał doktora Wałczyńskiego na śmierć, argumentując, że był to czyn skierowany przeciwko narodowi niemieckiemu. Doktor Wałczyński przez ponad rok, aż do wyzwolenia, oczekiwał każdego dnia na wykonanie kary śmierci, co przez polskich prawników z okresu okupacji zostało jednoznacznie ocenione jako ,szczególna tortura, nieprzewidziana w żadnym ustawodawstwie” oraz „sadyzm”. Za: WrZYSZCZ, Okupacyjne sadownictwo, s. 214-215.

${ }^{37}$ Dla przykładu osławione rozporządzenie o prawie karnym dla Polaków i Żydów na przyłączonych terenach wschodnich z 4 grudnia 1941 r. (Verordnung über die Strafrechtspflege gegen Polen und Juden in den eingegliederten Ostgebieten. Vom 4. Dezember 1941, RGB1 1941, cz. I, s. 759) nie obowiązywało w GG. Podkreślenia wymaga także fakt, że zupełnie inna była sytuacja prawno-społeczna Polaków w GG i na terenach wcielonych do Rzeszy. W grudniu 1942 r. na naradzie sędziów niemieckich w GG w jednym z głównych referatów wyraźnie podkreślono, że na terenach wcielonych do Rzeszy ,zgodnie z celami politycznymi Polacy byli odpryskami i mieli zostać wyparci”, wiązało się to z poddaniem ich specjalnemu prawu, a GG „stanowiło (na razie) przestrzeń życiową dla Polaków”. WRZYSZCZ, Okupacyjne sądownictwo, s. 385.

${ }^{38}$ Rozporządzenie o sądownictwie polskim w Generalnym Gubernatorstwie z 19 lutego 1940 r., Dz. RGGOP, cz. I, nr 13, s. 64, § 1 ust. 2. Sądy polskie stosowały głównie przedwojenne prawo, zastosowanie miałby więc art. 233 kodeksu karnego z 1932 r. zakazujący aborcji z dwoma wyjątkami (z powodu ścisłych wskazań medycznych; gdy ciąża zaistniała w wyniku zgwałcenia, kazirodztwa bądź współżycia z nieletnią poniżej lat 15).

${ }^{39}$ Trials of War Crminials, t. IV, s. 613.
} 


\section{OBOWIĄZEK I PRZYMUS PRACY}

W obrębie prawa pracy należy przytoczyć ważne akty normatywne z $1939 \mathrm{r}^{40}$ Już w pierwszym dniu istnienia GG Hans Frank wydał rozporządzenie wprowadzające obowiązek pracy dla wszystkich mieszkańców tego tworu okupacyjnego. Od razu jednak zastrzegł, że w stosunku do ludności żydowskiej ustanowił równolegle odrębne przepisy. Obowiązkowi pracy podlegały osoby od 18-tego roku życia do 60-tego roku życia. Przepisy wykonawcze do tego rozporządzenia miał wydać kierownik Wydziału Pracy w Urzędzie Generalnego Gubernatora. W tym samym dniu (26 października 1939 r.) weszło w życie rozporządzenie odnoszące się do Żydów, w którym użyto mocniejszego określenia: przymus pracy i nie zakreślono żadnych granic wiekowych. Kompetencje do tworzenia przepisów wykonawczych uzyskał w tym przypadku wyższy dowódca SS i policji ${ }^{41}$. I właśnie w przepisach wykonawczych wprowadzono uregulowanie dotyczące dzieci żydowskich. W dniu 12 grudnia 1939 r. wydał je wyższy dowódca SS i policji Friedrich Wilhelm Krüger. Dwa dni później Hans Frank ustanowił rozporządzenie odnoszące się do dzieci polskich. Przepisy podpisane przez Krügera były zdecydowanie bardziej surowe. Rozszerzały one granice wiekowe na wiek od ukończenia 14-tego roku życia do ukończenia 60-tego roku życia. Przymus pracy miał być realizowany w obozach, a jego czas wynosił w zasadzie 2 lata, ale mógł być przedłużony, jeśli „,cel wychowawczy przymusu pracy nie został osiągnięty”. Wyższy dowódca SS i policji sformułował bardzo szczegółowe przepisy co do sposobu egzekwowania przymusu pracy, a ich naruszenie zagrożone było surową karą ciężkiego więzienia do 10 lat ${ }^{42}$. Wyraźnie łagodniejsze prawo ustanowił Frank. Upoważnił on szefów okręgowych (guberna-

\footnotetext{
${ }^{40}$ Więcej na temat warunków pracy dzieci w: Cz. ŁUCZAK, Eksploatacja sity roboczej polskich dzieci przez III Rzesze, [w:] Dzieci i młodzież, s. 266-269; M. Venken, Child forced labour: an analysis of ego documents throughout time, „European Review of History” 22 (2015), z. 2, s. 368-388.

${ }^{41}$ WeH, Prawo Generalnego, A 330, rozporządzenie o wprowadzeniu obowiązku pracy dla polskiej ludności Generalnego Gubernatorstwa z 26 października 1939 r., paragraf 1, 5, A 425, rozporządzenie o wprowadzeniu przymusu pracy dla ludności żydowskiej Generalnego Gubernatorstwa z 26 października 1939 r., paragraf 1, 2; A. WRZYSZCZ, Ustawodawstwo antyżydowskie wprowadzone przez okupanta niemieckiego w Generalnym Gubernatorstwie (1939-1945), [w:] Scientia nihil est quamveritatis imago. Studia ofiarowane Profesorowi Ryszardowi Szczygłowi w siedemdziesięciolecie urodzin, red. A. Sochacka, P. Jusiak, Lublin: Wydawnictwo Uniwersytetu Marii CurieSkłodowskiej 2014, s. 998-1007; TENŻE, Z problematyki segregacji narodowościowej i rasowej ludności $w$ systemie prawa i sądownictwa niemieckiego Generalnego Gubernatorstwa (1939-1945), [w:] Spoteczeństwo a wtadza. Ustrój, prawo, idee, red. J. Przygodzki, M.J. Ptak, Wrocław: Wydawnictwo Kolonia Limited 2010, s. 800-802.

${ }^{42}$ WeH, Prawo Generalnego, A 427, Drugie postanowienie wykonawcze do rozporządzenia z dnia 26 października 1939 r. o wprowadzeniu przymusu pracy dla ludności żydowskiej Generalnego Gubernatorstwa. Postanowienie o sporządzeniu spisu z 12 grudnia 1939 r., paragraf 1-7.
} 
torów dystryktów) do rozciągania obowiązku pracy ludności polskiej w GG na młodzież między 14 -tym a 18 -tym rokiem życia ${ }^{43}$. Sprecyzował, że zatrudnienie dzieci „należy przystosować do zdolności roboczej”,44. Rozporządzenie to nie zawierało własnych sankcji karnych ${ }^{45}$.

\section{MOŻLIWOŚCI ZDOBYWANIA WYKSZTAŁCENIA}

Ustawodawstwo niemieckie w GG przewidywało podział szkolnictwa według kryterium narodowościowego. Dzieci narodowości niemieckiej mogły uczęszczać tylko do szkół niemieckich, a dzieci polskie tylko do szkół polskich ${ }^{46}$. Szkoły niemieckie powstawać miały we wszystkich tych miejscowościach, w których zamieszkiwało 10 dzieci niemieckich podlegających obowiązkowi szkolnemu. W niemieckich szkołach uczyć mogli tylko nauczyciele niemieccy.

Możliwość kształcenia polskich dzieci i wprowadzone w tym zakresie przepisy prawne obrazują najlepiej słowa Hansa Franka wyrażone 31 października 1939 r. na spotkaniu z ministrem propagandy Rzeszy Goebbelsem: „Polakom należy pozostawić tylko takie możliwości kształcenia się, które okażą im beznadziejność ich położenia narodowego, ${ }^{, 47}$. Funkcjonowały wyłącznie oficjalne szkoły powszechne oraz szkoły zawodowe. Rozporządzenie o szkolnictwie pomijało kwestie szkół średnich,

\footnotetext{
${ }^{43}$ Faktycznie jednak, zwłaszcza po 1942 r. zdarzały się przypadki zmuszania do pracy dzieci jeszcze młodszych. Jak podnoszono w powojennych opracowaniach lekarskich, niemieccy naziści „,...] powodowali krańcowe wycieńczenie dzieci w wieku od ośmiu do dziesięciu lat, zmuszając je do tak samo ciężkiej pracy jak dorosłych. Praca ponad siły, bicie i znęcanie się szybko wyczerpywały dzieci, które wówczas zabijano". Cyt. za: Cz. PILICHOwsKi, Sytuacja dzieci polskich w latach drugiej wojny światowej, [w:] Dzieci i młodzież, s. 35.

${ }^{44}$ Ograniczenie to miało charakter wyłącznie pozorny. Nie chodziło o przystosowanie zatrudnienia do potrzeb i szczególnych warunków osobistych młodocianych, lecz do zakresu ich eksploatacji, tego ,ile mogli z siebie dać”. Do młodocianych poza tym stosowano te same przepisy co do dorosłych. S. GRZYBOwSKI, Normy wydane przez władze niemieckie dla zakresu stosunków pracy na obszarze tzw. Generalnej Guberni, [w:] Ekspertyzy i orzeczenia przed Najwyższym Trybunatem Narodowym, t. III, red. Cz. Pilichowski, Warszawa: Ministerstwo Sprawiedliwości - Główna Komisja Badania Zbrodni Hitlerowskich w Polsce 1980, s. 151.

${ }^{45}$ WeH, Prawo Generalnego, A 331, rozporządzenie o rozciąganiu obowiązku pracy dla ludności polskiej Generalnego Gubernatorstwa z 14 grudnia 1939 r., paragraf 1.

${ }^{46}$ Rozporządzenie o szkolnictwie w Generalnym Gubernatorstwie z 31 października 1939 r., Dz. RGGOP, nr 3, s. 18, § 1 .

${ }^{47}$ S. PIOTROwSKI, Dziennik Hansa Franka, Warszawa: Wydawnictwo Prawnicze 1956, s. 396. Wytyczne w zakresie szkolnictwa przekazał także H. Himmler: „Dla nieniemieckiej ludności Wschodu nie mogą istnieć wyższe szkoły niż 4-klasowa szkoła ludowa. Celem takiej szkoły ma być wyłącznie: proste liczenie, najwyżej do 500, napisanie nazwiska, nauka, że nakazem Bożym jest posłuszeństwo wobec Niemców, uczciwość, pilność i grzeczność. Czytania nie uważam za konieczne". PilichowsKi, Sytuacja dzieci polskich, s. 36.
} 
co zinterpretowane zostało jako nakaz likwidacji gimnazjów i liceów. Ograniczony został istotnie program nauczania, wykluczono przedmioty istotne $\mathrm{z}$ punktu widzenia narodowego, zaprzestano więc nauki: historii, geografii Polski, historii literatury polskiej, nauki o współczesnej Polsce oraz, co ciekawe, gimnastyki ${ }^{48}$.

Możliwe było również działanie prywatnych szkół żydowskich, kwestie te regulowało rozporządzenie z 31 sierpnia 1940 r. o szkolnictwie żydowskim w Generalnym Gubernatorstwie ${ }^{49}$. Zakładanie i utrzymywanie szkół żydowskich pozostawiono w gestii Rad Żydowskich (Judenrat) ${ }^{50}$. Rada Żydowska odpowiadała także za wykształcanie i dokształcanie nauczycieli, mających uczyć w szkołach żydowskich. Była to jedyna możliwość kształcenia przewidziana dla dzieci żydowskich, poza tym obostrzeniem pozostałe kwestie obowiązku szkolnego regulować miały przepisy polskie $(\S 3)$. Szkoły te miały status szkół prywatnych, oprócz żydowskich szkół powszechnych możliwe było tworzenie żydowskich szkół fachowych (zawodowych) ${ }^{51}$. W styczniu 1941 r. przedstawiciele Rady Żydowskiej w Lublinie zwrócili się do Rady Żydowskiej w Krakowie z pytaniem o program nauczania w powszechnej szkole krakowskiej. Celem miało być ujednolicenie kształcenia w tego typu szkołach ${ }^{52}$. W odpowiedzi krakowska Rada Żydowska przedstawiła program nauczania, który został dopiero przekazany do akceptacji władzom niemieckim. Przewidywał on naukę: judaistyki, języka polskiego, rachunków, geografii, przyrody, rysunku, zajęć praktycznych, śpiewu oraz ćwiczeń cielesnych. Rada Żydowska w Krakowie na życzenie grona rodziciel-

\footnotetext{
${ }^{48}$ Założenia do nowych podstaw programowych pochodziły z memoriału Sprawy traktowania ludności byłych polskich obszarów z rasowo-politycznego punktu widzenia, autorstwa dr E. Wetzla i dr G. Hechta z 25 listopada 1939 r. Więcej w: K. PoSPIESZALSKI, Hitlerowskie „prawo” okupacyjne w Polsce, cz. I Ziemie „wcielone” do Rzeszy, „Documenta Occupationis” t. V, Poznań: Instytut Zachodni 1952, s. 2-28.

${ }^{49}$ Rozporządzenie o szkolnictwie żydowskim z 31 sierpnia 1940 r., Dz. RGG 1940, cz. I, nr 510, s. 258.

${ }^{50}$ Szkoły w znacznym stopniu utrzymywane były ze składek rodzicielskich. W Grodzisku rodzice płacili od 2 zł do 10 zł miesięcznie (nie wiadomo od czego zależała wysokość czesnego), od opłat zwolniono 180 najbiedniejszych dzieci, szkoła utrzymywana była także z subsydium Magistratu. Protokół zebrania Rady Żydowskiej w Grodzisku Mazowieckim z 6 stycznia 1941 r., [w:] Archiwum Ringelbluma. Konspiracyjne Archiwum Getta Warszawy, t. VI, oprac. A. Bańkowska, Warszawa: Wydawnictwo DiG 2012, s. 573.

${ }^{51}$ Rozporządzenie o szkolnictwie żydowskim z 31 sierpnia 1940 r., Dz. RGG 1940, cz. I, nr 510, s. 258, § 2 ust. 1-4. Możliwość tworzenia kursów zawodowych została dopuszczona dopiero po utworzeniu gett, za: Pismo Wydziału Szkolnictwa Starostwa Powiatowego Sochaczew-Błonie do kierownika prywatnej szkoły żydowskiej w Grodzisku z 16 grudnia 1940 r., [w:] Archiwum Ringelbluma, s. 547.

${ }^{52}$ APL, Rada Żydowska w Lublinie, sygn. 1/29, k. 7. Pismo Rady Żydowskiej w Lublinie do Rady Żydowskiej w Krakowskie z 7 stycznia 1941 r. w sprawie programu nauczania.
} 
skiego zdywersyfikowała w programie nauczanie przedmiotów judaistycznych na trzech poziomach (w pierwszej grupie w każdej klasie po 10 godzin tygodniowo zajęć judaistycznych; w drugiej grupie w klasach 1-2 po 10 godzin tygodniowo, i w zwiększonym wymiarze od klasy 3; w grupie trzeciej od 12 do 18 godzin, w zależności od klasy), nauczanie przedmiotów ogólnokształcących miało odbywać się w identycznym wymiarze czasowym w każdej z grup ${ }^{53}$. Nie wiadomo jaka była odpowiedź władz niemieckich na zaproponowany program nauczania, na pewno jednak nie realizowano kształcenia w przedstawionym kształcie. Władze niemieckie zgodziły się jedynie na nauczanie w języku jidysz lub hebrajskim, zabroniono nauki języka polskiego, miało to na celu dalsze odseparowanie ludności żydowskiej ${ }^{54}$. W Lublinie z powodów lokalowych nie udało się utworzyć szkoły w gettcie, pomimo że liczbę dzieci podlegających szkolnictwu powszechnemu na początku $1941 \mathrm{r}$. szacowano na $5000^{55}$. Zorganizowano jedynie kursy języka jidysz i hebrajskiego. Na kurs hebrajskiego dla początkujących, organizowany od marcu 1941 r. zapisało się 14 słuchaczy w wieku od 14 lat wzwyż $\dot{z}^{56}$. Rada Żydowska w Lublinie starała się także zorganizować kursy o charakterze zawodowym, mające kształcić ogrodników, krawców damskich i męskich oraz ślusarzy ${ }^{57}$.

Niemieccy okupanci pozwolili na tworzenie także odrębnych szkół ukraińskich, co zgodnie z propagandą niemiecką miało naprawić istniejącą w polskiej przedwojennej praktyce szkolnej niesprawiedliwość względem mniejszości narodowych, tj. niemożność nauczania w języku ukraińskim ${ }^{58}$. W ukraińskiej literaturze dominuje teza, że w okresie istnienia GG ukraińskie szkolnictwo było liczebnie bardziej

\footnotetext{
${ }^{53}$ Tamże, k. 8-11. Pismo Rady Żydowskiej w Krakowie z 24 stycznia 1941 r. w sprawie programu nauczania w powszechnej szkole żydowskiej.

${ }^{54}$ T. RADZIK, Lubelska dzielnica zamknięta, Lublin: Wydawnictwo Uniwersytetu Marii CurieSkłodowskiej 1999, s. 208. Jak wskazywał radca szkolny ze Starostwa Powiatowego SochaczewBłonie: „W szkołach żydowskich język niemiecki nigdy nie może być językiem nauczania. Niedopuszczalne jako języki nauczania są także ukraiński i polski. Językiem nauczania w szkołach żydowskich może być wyłącznie język żydowski w postaci albo nowohebrajskiego, tak jak mówi się nim potocznie np. w Palestynie, albo też żydowskiego, który zawiera w sobie elementy dialektu frankońskiego [w rzeczywistości jidysz w dużym stopniu oparty jest na języku niemieckim - dopisek H.M.] i jest szeroko rozpowszechniony na terenie Generalnego Gubernatorstwa”. Cyt. za: Pismo Wydziału Szkolnictwa Starostwa Powiatowego Sochaczew-Błonie do kierownika prywatnej szkoły żydowskiej w Grodzisku z 14 stycznia 1941 r., [w:] Archiwum Ringelbluma, s. 548.

${ }^{55}$ Radzik, Lubelska dzielnica, s. 209.

${ }^{56}$ APL, Rada Żydowska w Lublinie, sygn. 1/29, k. 19. Sprawozdanie z czynności kursu języka hebrajskiego z 18 kwietnia $1941 \mathrm{r}$.

${ }^{57}$ APL, Rada Żydowska w Lublinie, sygn. 1/3, k. 125. Protokół z posiedzenia Rady Żydowskiej w Lublinie w dniu 1 marca $1941 \mathrm{r}$.

${ }^{58}$ A. WATZKE, Wissenschaft, Erziehung und Volksbildung, [w:] Das General-Gouverement, red. M. du Prel, Würzburg: Konrad Triltsch Verlag 1942, s. 171.
} 
rozwinięte niż w II Rzeczypospolitej (w zakresie szkolnictwa powszechnego pod koniec wojny: 4,5 tys. szkół, 612 tys. uczniów i 10 tys. nauczycieli) ${ }^{59}$. Na pewno znacznie lepiej wyglądała sytuacja ukraińskich szkół w porównaniu do polskich, możliwe było bowiem tworzenie ukraińskich szkół średnich ogólnokształcących, niemieckie władze pozwoliły także na utworzenie Państwowych Kursów Zawodowych we Lwowie, stanowiących namiastkę szkoły wyższej ${ }^{60}$.

Dzieci w GG mogły kształcić się także w szkołach prywatnych, jedynie jednak powszechnych i zawodowych (rzemieślniczych i rolniczych) ${ }^{61}$. Niemieckie władze niechętnie odnosiły się do szkół prywatnych, uznając, że lepiej, aby polskie dzieci uczyły się w szkołach publicznych, które łatwiej było nadzorować ${ }^{62}$. Dzieci mogły być także kształcone w ramach nauki prywatnej poza szkołą ${ }^{63}$.

\section{ZAPOMOGI PRZYZNAWANE DZIECIOM}

\subsection{DZIECI NIEMIECKIE}

Zapomogi dla dzieci niemieckich przyznawano na różnych podstawach prawnych. Pomoc materialną dla zabezpieczenia koniecznych potrzeb życiowych przyznawano członkom rodzin osób przynależnych do narodu niemieckiego, powołanych z Generalnego Gubernatorstwa do służby w formacjach Waffen-SS ${ }^{64}$. Uprawnione do zapomogi były ślubne i nieślubne uznane i przyjęte za własne dzieci, pasierbowie oraz nieślubne dzieci powołanego, jeżeli powołany był ich żywicielem, a ojcostwo zostało stwierdzone sądownie lub przez uznanie. Przyznawano zapomogę dla pokrycia bieżących i koniecznych potrzeb życiowych, dodatek czynszowy dla pokrycia potrzeb mieszkaniowych oraz części na pokrycie ubezpieczenia na wypadek choroby $(\S \S 1-3)$.

\footnotetext{
${ }^{59}$ Dla porównania dane nazistowskie z listopada 1940 r.: szkół powszechnych: 910, uczniów: 91 411, nauczycieli: 1 398, za: Watzke, Wissenschaft, s. 172.

${ }^{60}$ G. Hryciuk, [rec.] Natalia W. Antoniuk, Ukrajinśke kulturne żyttia w Heneralnij Huberniji (1939-1944 rr.), Lwiw 1997, „Dzieje Najnowsze” 30 (1998), nr 1, s. 207.

${ }^{61}$ Rozporządzenie o szkołach prywatnych w Generalnym Gubernatorstwie z 12 kwietnia 1940 r., Dz. RGGOP, cz. I, nr 26, s. 134.

${ }^{62}$ Raporty Ludwiga Fischera gubernatora dystryktu warszawskiego 1939-1945, wybór i oprac. K. Dunin-Wąsowicz, M. Getter, J. Kaźmierski, J. Kaźmierska, Warszawa: Książka i Wiedza 1987, s. 157.

${ }^{63}$ Rozporządzenie o nauce prywatnej w Generalnym Gubernatorstwie z 23 kwietnia 1940 r., Dz. RGGOP, cz. I, nr 33, s. 160.

${ }^{64}$ Rozporządzenie o udzielaniu zapomóg rodzinnych członkom rodzin powołanych z Generalnego Gubernatorstwa do Waffen-SS przynależnych do narodu niemieckiego z 17 stycznia 1940 r., Dz. RGGOP, cz. I, nr 4, s. 11.
} 
Jeszcze inna pomoc materialna przysługiwała dzieciom niemieckim na podstawie rozporządzenia w sprawie opieki nad przynależnymi do narodu niemieckiego w Generalnym Gubernatorstwie ${ }^{65}$. Przynależni do narodu niemieckiego, którzy nie byli lub byli w niewystarczający sposób w stanie pokryć niezbędnych wydatków na utrzymanie własne oraz swojej rodziny, mieli mieć zapewnione potrzeby życiowe $\mathrm{z}$ budżetu GG, w granicach ustanowionego rozporządzenia. Szczególną opieką mieli zostać otoczeni nieletni potrzebujący pomocy $(\S 1)$. Na dzieci poniżej 16-tego roku życia przysługiwało miesięcznie 20 złotych, rodzinom mającym powyżej 3 dzieci poniżej 16-tego roku życia na każde kolejne dziecko przysługiwał dodatek powiększony o 10 złotych (§ 4).

W marcu 1942 r. ustanowiono rozporządzenie, które przyznawało dzieciom niemieckim specjalną zapomogę ${ }^{66}$. Celem przyznania zapomogi miało być „ulżenie ciężarom rodzinnym zdrowym i wartościowym pod względem społecznym niemieckim rodzinom" ( $\$ 1$ RZDGG). Zapomoga wypłaca była głowie rodzinny i wynosiła 20 zł na każde dziecko, któremu przysługiwała zapomoga. Warunkiem otrzymania takiego wsparcia było posiadanie przez głowę rodziny obywatelstwa, narodowości albo pochodzenia niemieckiego (w przypadku osób pochodzenia niemieckiego dodatkowym warunkiem było zagwarantowanie niemieckiego wychowania wszystkich dzieci), posiadanie co najmniej 3 małoletnich dzieci oraz faktyczne przebywanie na terenie GG, jeżeli głowa rodziny miała zwykły pobyt w Rzeszy lub w Protektoracie Czech i Moraw, zapomoga mogła być wypłacana, jeżeli ośrodek faktycznej gospodarki domowej, czyli przebywanie pozostałych członków rodziny, znajdował się w GG (§ 3 ust. 1-2 RZDGG). W takiej sytuacji zapomoga przysługiwała na trzecie dziecko i każde następne, przynależne do gospodarstwa domowego ( $\$ 4$ ust. 1 pkt 1 RZDGG). Pomoc materialna przewidziana przez rozporządzenie przysługiwała także bez względu na liczbę małoletnich dzieci, gdy głowa rodziny była ograniczona w możliwości zarobkowania co najmniej w 85\%, w sytuacjach w których głową rodziny była samotna matka oraz gdy rodzina przyjęła do gospodarstwa domowego sieroty lub dzieci samotnej kobiety ( $\$ 3$ ust. 3 RZDGG). W wymienionych powyżej sytuacjach, w dwóch pierwszych przypadkach zapomoga przysługiwała na każde z dzieci, a w trzecim przypadku na każde z przyjętych dzieci (§ 4 ust. 1 pkt 2-3 RZDGG).

Rozporządzenie posługiwało się pojęciami dziecka i przynależności do gospodarstwa domowego, które wymagały prawnego zdefiniowania. Dzieci definiowa-

\footnotetext{
${ }^{65}$ Rozporządzenie w sprawie opieki na przynależnymi do narodu niemieckiego w Generalnym Gubernatorstwie z 27 marca 1940 r., Dz. RGGOP, cz. I, nr 23, s. 117.

${ }^{66}$ Rozporządzenie o przyznaniu zapomogi na dzieci Niemcom w Generalnym Gubernatorstwie (RZDGG) z 10 marca 1942 r., Dz. RGG, nr 23, s. 125.
} 
no jako potomków głowy rodziny, jego pasierbów, dzieci przysposobione oraz wychowanków, a także potomków tych osób, jeżeli były „krwi niemieckiej lub rasowo pokrewnej" ( $§ 4$ ust. 2 RZDGG). Była to więc rozszerzona definicja, obejmująca nie tylko sytuacje relacji rodzinnych przewidzianych przez prawo, ale również wychowanków, czyli najprawdopodobniej dzieci niespokrewnione, które były objęte faktyczną, nie prawną, opieką. Przez dzieci rozumiano także wszystkich zstępnych wymienionego kręgu osób. Przyjęta definicja odnosiła się więc do rodzin wielopokoleniowych. Używane przez rozporządzenie pojęcie głowy rodziny nie oznaczało więc wyłącznie matki i żony, czy ojca i męża, lecz odnosiło się do szerszego kręgu osób.

Dzieci były przynależne do gospodarstwa, jeżeli mieszkały w jednym domu z osobą uprawnioną do pobierania zapomogi (głową rodziny) albo za zgodą tej osoby przebywały poza domem w celach wychowawczych lub wykształcenia, w celu odwiedzenia krewnych albo były poza domem w celach wypoczynkowych ( 55 ust. 1 RZDGG). Wymieniono także katalog osób uznawanych za przynależnych do gospodarstwa domowego. Byli to m.in. małoletni przynależni do Służby Pracy, do Sił Zbrojnych, do Waffen-SS, czy członkinie Niemieckiego Czerwonego Krzyża, do osiągnięcia określonego stanowiska lub stopnia (§ 5 ust. 2 RZDGG).

O przyznaniu zapomogi dla dzieci decydował Inspektor Skarbowy w starostwie powiatowym albo miejskim na wniosek głowy rodziny. W procedurze przyznawania zapomóg dla dzieci rolę pełnił także zwierzchnik NSDAP (Kreisstandortführer), który mógł sprzeciwić się decyzji o jej przyznaniu, jeżeli uznał, że przyznana zapomoga nie będzie realizowała głównych celów, dla których została ustanowiona. Zażalenie na decyzję zwierzchnika NSDAP rozpatrywane było przez wyższą partyjną placówkę służbową (§§ 6-10 RZDGG).

Niemieckie rodziny otrzymały dodatkowe wsparcie finansowe na prowadzenie gospodarstwa domowego ${ }^{67}$. Przyznany został specjalny dodatek finansowy, aby zabezpieczyć prowadzenie odpowiedniego gospodarstwa domowego i przez to także w celu poparcia wychowania dzieci (§ 1 RPGD). Zakres uprawnionych do pobierania dodatku był zasadniczo taki sam jak w przypadku rozporządzenia o przyznaniu zapomogi na dzieci Niemcom ( $\S 2-3$ RPGD). Dodatek wynosił 40 zł miesięcznie na każde dziecko zdatne do otrzymywania zadatku (§ 5 RPGD). Rodzinom, których dochód nie przekraczał 4200 zł udzielano dodatku już na pierwsze dziecko. Przy wyższych progach dochodowych wzrastała liczba dzieci, od których przyznawano dodatek (§ 4 RPGD).

\footnotetext{
${ }^{67}$ Rozporządzenie w sprawie udzielenia Niemcom w Generalnym Gubernatorstwie dodatku na prowadzenie gospodarstwa domowego (RPGD) z 15 sierpnia 1942 r., Dz. RGG, nr 68, s. 442.
} 


\subsection{DZIECI POLSKIE}

Na podstawie rozporządzenia o ofiarach wojennych z 20 grudnia 1939 r. ${ }^{68}$ oraz drugiego postanowienia wykonawczego do tego rozporządzenia ${ }^{69}$ przyznano polskim dzieciom, których ojcowie polegli w związku ze służbą wojskową, zapomogę w wymiarze przewidzianym przez polskie przepisy tj. ustawę z 17 marca $1932 \mathrm{r}$. o zaopatrzeniu inwalidzkim ${ }^{70}$. Świadczenia tego odmówiono dzieciom żydowskim (§ 5). Władze niemieckie przyznały świadczenie także sierotom po emerytowanych urzędnikach i wojskowych. Zapomogę w wysokości 10 złotych miesięcznie otrzymywały dzieci do ukończenia 14-tego roku życia. W tym wypadku również zapomogi nie przyznano Żydom ${ }^{71}$.

\section{REGLAMENTACJA OBROTU TOWARAMI DZIECIĘCYMI}

Trudny los dzieci w Generalnym Gubernatorstwie ujawniał się nawet w regulacjach związanych z obrotem handlowym. Na mocy rozporządzenia o założeniu urzędu gospodarowania surowcami i towarami włókienniczymi w Generalnym Gubernatorstwie z 12 kwietnia 1940 r. oraz wydanych do tego rozporządzenia zarządzeń reglamentowano obrót towarami włókienniczymi i niewłókienniczymi ${ }^{72}$. Wprowadzono monopol przedsiębiorstw handlu detalicznego oraz kartki zapotrzebowania, wydawane na wniosek przez starostów powiatowych i miejskich, była to jedyna możliwość nabycia wymienionych towarów. Co istotne, rozróżniano cztery grupy formularzy dla poszczególnych wnioskodawców. Oddzielne formularze były dla obywateli Rzeszy, dla ludności GG pracującej w interesie niemieckim, dla przynależnych do narodu niemieckiego oraz dla ,innej ludności Generalnego Guber-

\footnotetext{
${ }^{68}$ Rozporządzenie o zapomogach dla odbiorców rent wojskowych byłego państwa polskiego i osób pozostałych po nich (rozporządzenie o ofiarach wojennych) z 20 grudnia 1939 r., Dz. RGGOP, cz. I, nr 1, s. 1.

${ }^{69}$ Drugie postanowienie wykonawcze do rozporządzenia z 20 grudnia 1939 r. o zapomogach dla odbiorców rent wojskowych byłego państwa polskiego i osób pozostałych po nich (rozporządzenie o ofiarach wojennych) z 10 marca 1940 r., Dz. RGGOP, cz. II, nr 19, s. 167.

${ }^{70}$ Dz. U. z 1934 r. Nr 5, poz. 31.

${ }^{71}$ Rozporządzenie o tymczasowym uregulowaniu wypłaty zapomóg emerytom byłego państwa polskiego i polskich związków samorządowych z 9 grudnia 1939 r., Dz. RGGOP, nr 12, s. 206; pierwsze postanowienie wykonawcze do rozporządzenia z 9 grudnia 1939 r. o tymczasowym uregulowaniu wypłaty zapomóg emerytom byłego państwa polskiego i polskich związków samorządowych z 11 kwietnia 1940 r., Dz. RGGOP, cz. II, nr 27, s. 209.

${ }^{72}$ Rozporządzenie o założeniu urzędu gospodarowania surowcami i towarami włókienniczymi w Generalnym Gubernatorstwie z 12 kwietnia 1940 r., Dz. RGGOP, cz. I, nr 27, s. 139.
} 
natorstwa" ${ }^{, 73}$. Wprowadzenie poszczególnych rodzajów formularzy miało spowodować rozwarstwienie w przyznawaniu kartek zapotrzebowania, i gorsze traktowanie poszczególnych grup, zgodnie z przyjętą hierarchią. Oddzielne zarządzenie wydane zostało dla obrotu bielizną dla noworodków, dla małych dzieci, innej bielizny drobnej i środków do szycia. Zarządzeniem tym wprowadzono limity towarów, jakie można było maksymalnie żądać na jednej kartce zapotrzebowania ${ }^{74}$. I tak dla przykładu dla noworodków do 12 miesięcy można było wpisać zapotrzebowanie na 12 pieluszek czy 4 powijaki ${ }^{75}$. Biorąc pod uwagę wcześniej opisaną trudność w dostępie do kart zapotrzebowania, różny status poszczególnych dzieci ujawniał się nawet $w$ tak prozaicznych aspektach jak dostęp do bielizny i ubranek.

\section{PODSUMOWANIE}

Problematyka statusu dziecka w prawie dotyczy zazwyczaj przysługujących mu praw oraz jego ochrony jako istoty w życiu społecznym bezbronnej, wymagającej więc szczególnego zainteresowania i traktowania. Powyższe reguły zostały praktycznie w całości złamane w ustawodawstwie niemieckim w GG. Przeprowadzona analiza ujawniła dodatkowo, że ustawodawstwo wpływające na status prawny dzieci nie miało charakteru uporządkowanego. Prawodawcy w GG nie prowadzili zaplanowanej i usystematyzowanej działalności ustawodawczej względem dzieci. Wprowadzone bowiem przez niemieckich okupantów przepisy dotyczące dzieci odzwierciedlały najważniejsze cele polityki nazistowskiej i im zostały w całości podporządkowane, dlatego też dotyczyły pojedynczych kwestii. Ustawodawstwo niemieckie w Generalnym Gubernatorstwie, pomimo swego nieuporządkowanego charakteru, służyło do pogorszenia losu dzieci nie mających niemieckiego obywatelstwa albo narodowości.

\footnotetext{
${ }^{73}$ Zarządzenie nr 2 kierownika urzędu gospodarowania surowcami i towarami włókienniczymi w Generalnym Gubernatorstwie o oddaniu towarów włókienniczych i niewłókienniczych towarów krótkich przez przedsiębiorstwa handlu detalicznego łącznie $\mathrm{z}$ handlem domokrążnym konsumentom z 15 kwietnia 1940 r., Dz. RGGOP, cz. II, nr 28, s. 215.

${ }^{74}$ Zarządzenie nr 8 kierownika urzędu gospodarowania surowcami i towarami włókienniczymi w Generalnym Gubernatorstwie o oddaniu bielizny dla noworodków, dla małych dzieci, innej bielizny drobnej i środków do szycia przez przedsiębiorstwa handlu detalicznego (łącznie z handlem domokrążnym) konsumentom z 6 maja 1940 r., Dz. RGGOP, cz. II, nr 39, s. 306.

${ }^{75}$ Załącznik do $\S 1$ ust. 1 zarządzenia nr 8 kierownika urzędu gospodarowania surowcami i towarami włókienniczymi w Generalnym Gubernatorstwie o oddaniu bielizny dla noworodków, dla małych dzieci, innej bielizny drobnej i środków do szycia przez przedsiębiorstwa handlu detalicznego (łącznie z handlem domokrążnym) konsumentom z 6 maja 1940 r., Dz. RGGOP, cz. II, nr 39, s. 309.
} 
Rasistowskie poglądy odbijały się w zakresie statusu prawnego, ponieważ do jego ustalenia najważniejsze było pochodzenie dziecka, jakiej było narodowości, to ono wpływało na zakres praw i ochrony. Praktycznie pozbawione praw były dzieci żydowskie, nieporównywalnie lepszą pozycję prawną, od dzieci o innej narodowości miały zaś dzieci niemieckie. Nawet jednak tam, gdzie polepszano sytuację dzieci niemieckich, ujawniały się kwestie czysto polityczne.

Gospodarcza eksploatacja polskich obszarów oraz traktowanie Polaków i Żydów jako taniej siły roboczej, w odniesieniu do dzieci zastosowane zostały w przepisach rozciągających na nich przymus i obowiązek pracy, co doprowadziło do sytuacji, że ponad 700 tys. dzieci wykonywało pracę fizyczną ${ }^{76}$. Szeroka penalizacja istotnych dla okupantów sfer życia społecznego i gospodarczego, traktowanie prawa karnego jako środka realizacji celów politycznych, także wpłynęły na prawny status dzieci nieniemieckich. Rozwarstwienie i odmienne traktowanie dzieci poszczególnych narodowości widać również w prawie do edukacji i rozwoju.

Wobec powyższego widać, że status prawny dzieci w ustawodawstwie niemieckim w GG urzeczywistniał, jak zresztą całe to ustawodawstwo, główne cele i zamierzenia nazistów. W przepisach dotyczących dzieci widoczne są wszystkie cechy prawa nazistowskiego: rasizm, pogwałcenie podstawowych zasad słuszności i sprawiedliwości. Można je nazwać więc prawem haniebnym - „ustawowym bezprawiem", normami mającymi jedynie formę prawną, będącymi zaś w swej istocie przekreśleniem zasad słuszności i sprawiedliwości ${ }^{77}$.

Powyższe dotyczy jednak sfery normatywnej, działań, które przybierały formę przepisów prawnych. W czasie niemieckiej okupacji wiele $\mathrm{z}$ podejmowanych działań odbywało się poza sferą normatywną, na mocy decyzji politycznych podejmowanych na różnego rodzaju szczeblach administracyjnych, policyjnych i wojskowych. To one doprowadziły do Holocaustu dzieci żydowskich, wysiedleń i germanizacji polskich dzieci z Zamojszczyzny, działalności Lebensbornów czy zagłady dzieci romskich, oraz wielu innych tragedii indywidualnych i zbiorowych. Bez chociażby wspomnienia o powyższych wydarzeniach powstałby obraz nie oddający rzeczywistego statusu dzieci w GG i ich tragicznego losu.

\footnotetext{
${ }^{76}$ W. THEISS, Sieroctwo wojenne polskich dzieci (1939-1945). Zarys problematyki, „Przegląd Pedagogiczny” 1 (2012), s. 80. Podobne dane podaje PILICHOwSKI, Sytuacja dzieci polskich, s. 38. Dane te oparte są o raport UNESCO Situation of Polish Children under the German Occupation z $1948 \mathrm{r}$.

${ }^{77}$ Więcej na ten temat: J. ZAJADŁO, Formuła Radbrucha. Filozofia prawa na granicy pozytywizти prawniczego i prawa natury, Gdańsk: Wydawnictwo Arche 2001.
} 


\section{BIBLIOGRAFIA}

\section{ŹRÓDŁA PRAWA}

Ustawa z dnia 17 marca 1932 r. o zaopatrzeniu inwalidzkim, Dz. U. z 1934 r. Nr 5, poz. 31.

Rozporządzenie Prezydenta Rzeczypospolitej z dnia 11 lipca 1932 r. - Kodeks karny, Dz. U. Nr 60, poz. 571.

Verordnung zum Schutz gegen jugendlische Schwerverbrecher vom 4. Oktober 1939, RGBl 1939, cz. I, nr 199, s. 2000

Rozporządzenie celem zwalczania czynów gwałtu w Generalnym Gubernatorstwie z 31 października 1939 r., Dz. RGGOP, nr 2, s. 10.

Rozporządzenie o szkolnictwie w Generalnym Gubernatorstwie z 31 października 1939 r., Dz. RGGOP, nr 3, s. 18.

Rozporządzenie o sądach specjalnych w Generalnym Gubernatorstwie z 15 listopada 1939 r., Dz. RGGOP, nr 6, s. 34.

Rozporządzenie o oznaczeniu Żydów i Żydówek w Generalnym Gubernatorstwie z 23 listopada 1939 r., Dz. RGGOP, nr 8, s. 61.

Rozporządzenie o tymczasowym uregulowaniu wypłaty zapomóg emerytom byłego państwa polskiego i polskich związków samorządowych z 9 grudnia 1939 r., Dz. RGGOP, nr 12, s. 206.

Rozporządzenie o zapomogach dla odbiorców rent wojskowych byłego państwa polskiego i osób pozostałych po nich (rozporządzenie o ofiarach wojennych) z 20 grudnia 1939 r., Dz. RGGOP, cz. I, nr 1, s. 1.

Rozporządzenie o udzielaniu zapomóg rodzinnych członkom rodzin powołanych z Generalnego Gubernatorstwa do Waffen-SS przynależnych do narodu niemieckiego z 17 stycznia 1940 r., Dz. RGGOP, cz. I, nr 4, s. 11.

Rozporządzenie o sądownictwie niemieckim w Generalnym Gubernatorstwie z 19 lutego 1940 r., Dz. RGGOP, cz. I, nr 13, s. 57.

Rozporządzenie o sądownictwie polskim w Generalnym Gubernatorstwie z 19 lutego 1940 r., Dz. RGGOP, cz. I, nr 13, s. 64.

Drugie postanowienie wykonawcze do rozporządzenia z 20 grudnia 1939 r. o zapomogach dla odbiorców rent wojskowych byłego państwa polskiego i osób pozostałych po nich (rozporządzenie o ofiarach wojennych) z 10 marca 1940 r., Dz. RGGOP, cz. II, nr 19, s. 167.

Rozporządzenie w sprawie opieki na przynależnymi do narodu niemieckiego w Generalnym Gubernatorstwie z 27 marca 1940 r., Dz. RGGOP, cz. I, nr 23, s. 117.

Pierwsze postanowienie wykonawcze do rozporządzenia z 9 grudnia 1939 r. o tymczasowym uregulowaniu wypłaty zapomóg emerytom byłego państwa polskiego i polskich związków samorządowych z 11 kwietnia 1940 r., Dz. RGGOP, cz. II, nr 27, s. 209.

Rozporządzenie o szkołach prywatnych w Generalnym Gubernatorstwie z 12 kwietnia 1940 r., Dz. RGGOP, cz. I, nr 26, s. 134.

Rozporządzenie o założeniu urzędu gospodarowania surowcami i towarami włókienniczymi w Generalnym Gubernatorstwie z 12 kwietnia 1940 r., Dz. RGGOP, cz. I, nr 27, s. 139.

Rozporządzenie o nauce prywatnej w Generalnym Gubernatorstwie z 23 kwietnia 1940 r., Dz. RGGOP, cz. I, nr 33, s. 160.

Zarządzenie nr 2 kierownika urzędu gospodarowania surowcami i towarami włókienniczymi w Generalnym Gubernatorstwie o oddaniu towarów włókienniczych i niewłókienniczych towarów krótkich przez przedsiębiorstwa handlu detalicznego łącznie $\mathrm{z}$ handlem domokrążnym konsumentom z 15 kwietnia 1940 r., Dz. RGGOP, cz. II, nr 28, s. 215. 
Zarządzenie nr 8 kierownika urzędu gospodarowania surowcami i towarami włókienniczymi w Generalnym Gubernatorstwie o oddaniu bielizny dla noworodków, dla małych dzieci, innej bielizny drobnej i środków do szycia przez przedsiębiorstwa handlu detalicznego (łącznie z handlem domokrążnym) konsumentom z 6 maja 1940 r., Dz. RGGOP, cz. II, nr 39, s. 306.

Rozporządzenie o definicji pojęcia „Żyd” w Generalnym Gubernatorstwie z 24 lipca 1940 r., Dz. RGGOP, cz. I, nr 48, s. 231.

Rozporządzenie o szkolnictwie żydowskim z 31 sierpnia 1940 r., Dz. RGG 1940, cz. I, nr 510, s. 258.

Verordnung über die Strafrechtspflege gegen Polen und Juden in den eingegliederten Ostgebieten vom 4. Dezember 1941, RGB1 1941, cz. I, s. 759.

Rozporządzenie o przyznaniu zapomogi na dzieci Niemcom w Generalnym Gubernatorstwie (RZDGG) z 10 marca 1942 r., Dz. RGG, nr 23, s. 125.

Rozporządzenie o prawie obowiązującym osoby pochodzenia niemieckiego z 30 listopada 1942 r., Dz. RGG, nr 106, s. 739-740.

Piąte postanowienie wykonawcze do rozporządzenia z 19 lutego 1940 r. o sądownictwie niemieckim w GG z 26 czerwca 1942 r., Dz. RGG, nr 58, s. 361.

Rozporządzenie w sprawie udzielenia Niemcom w Generalnym Gubernatorstwie dodatku na prowadzenie gospodarstwa domowego (RPGD) z 15 sierpnia 1942 r., Dz. RGG, nr 68, s. 442.

Verordnung zum Schutz von Ehe, Familie und Mutterschaft vom 9. März 1943, RGB1, cz. I, nr 27, s. 140 .

\section{ŹRÓDŁA ARCHIWALNE}

Archiwum Państwowe w Lublinie:

zespół Urząd Okręgu Lublin, sygn. 914.

zespół Rada Żydowska w Lublinie, sygn. 1/3; 1/29.

zespół Sąd Okręgowy w Lublinie, sygn. 3/14.

\section{ŹRÓDŁA DRUKOWANE}

Archiwum Ringelbluma. Konspiracyjne Archiwum Getta Warszawy, t. VI, oprac. A. Bańkowska, Warszawa: Wydawnictwo DiG 2012.

PosPiesZalski Karol M: Hitlerowskie „,prawo” okupacyjne w Polsce, cz. I Ziemie „wcielone” do Rzeszy, „Documenta Occupationis” t. V, Poznań: Instytut Zachodni 1952.

Raporty Ludwiga Fischera gubernatora dystryktu warszawskiego 1939-1945, wybór i oprac. K. Dunin-Wąsowicz, M. Getter, J. Kaźmierski, J. Kaźmierska, Warszawa: Książka i Wiedza 1987.

Trials of War Crminials before the Nuernberg Military Tribunals. „The Einsatzgruppen case”; „The RuSHA case", t. IV, Waszyngton 1949.

Trials of War Crminials before the Nuernberg Military Tribunals. „The RuSHA case”; „The Pohl case", t. V, Waszyngton 1949.

WATZKE Adolf: Wissenschaft, Erziehung und Volksbildung, [w:] Das General-Gouverement, red. M. du Prel, Würzburg: Konrad Triltsch Verlag 1942, s. 167-185.

WeH Albert: Prawo Generalnego Gubernatorstwa w układzie rzeczowym z objaśnieniami i szczegółowym skorowidzem, wyd. 3, Kraków: Institut für detusche Ostarbeit 1941. 


\section{LITERATURA}

ADAMSKA Jolanta: Organizowanie więzień sądowych na terenie Generalnego Gubernatorstwa, Zeszyty Majdanka t. XII (1987), s. 5-22.

GAŁAN Alina: Martyrologia dzieci i młodzieży w więzieniu na zamku w Lublinie, [w:] Dzieci i młodzież w latach drugiej wojny światowej, red. Cz. Pilichowski, Warszawa: Państwowe Wydawnictwo Naukowe 1982, s. 261-265.

GraSSMANN Gerhard O.: Die deutsche Besatzungsgesetzgebung während des 2. Weltkrieges, Studien des Instituts für Besatzungsfragen in Tübingen zu den deutschen Besetzungen im 2. Weltkrieg, Nr 14, Tübingen: Institut für Besatzungsfragen 1958.

GRÜNBERG Karol, OTRĘBA Bolesław: Hans Frank na Wawelu, Włocławek: Wyższa Szkoła Humanistyczno-Ekonomiczna we Włocławku 2001.

GRZYBOWSKI Stefan: Normy wydane przez władze niemieckie dla zakresu stosunków pracy na obszarze tzw. Generalnej Guberni, [w:] Ekspertyzy i orzeczenia przed Najwyższym Trybunałem Narodowym, t. III, red. Cz. Pilichowski, Warszawa: Ministerstwo Sprawiedliwości - Główna Komisja Badania Zbrodni Hitlerowskich w Polsce 1980, s. 146-163.

HRYCIUK Grzegorz: [rec.] Natalia W. Antoniuk, Ukrajinśke kulturne żyttia w Heneralnij Huberniji (1939-1944 rr.), Lwiw 1997, Dzieje Najnowsze 30 (1998), nr 1, s. 207-209.

HunT John: Out of Respect for Life: Nazi Abortion Policy in the Eastern Occupied Territories, Journal of Genocide Research 1 (1999), nr 3, s. 379-385.

KLAFKowski Alfons: Okupacja niemiecka w Polsce w świetle prawa narodów, Poznań: Wydawnictwo Instytutu Zachodniego 1946.

ŁUCZAK Czesław: Eksploatacja siły roboczej polskich dzieci przez III Rzeszę, [w:] Dzieci i młodzież w latach drugiej wojny światowej, red. Cz. Pilichowski, Warszawa: Państwowe Wydawnictwo Naukowe 1982, s. 266-269.

MAJER Diemut: Narodowo obcy w Trzeciej Rzeszy. Przyczynek do narodowo-socjalistycznego ustawodawstwa i praktyki prawniczej w administracji i wymiarze sprawiedliwości ze szczególnym uwzględnieniem ziem wcielonych do Rzeszy i Generalnego Gubernatorstwa, Warszawa: Wydawnictwo Prawnicze 1989.

PILICHOwSKI Czesław: Sytuacja dzieci polskich w latach drugiej wojny światowej, [w:] Dzieci i młodzież w latach drugiej wojny światowej, red. Cz. Pilichowski, Warszawa: Państwowe Wydawnictwo Naukowe 1982, s. 17-39.

PIOTROWSKI Stanisław: Dziennik Hansa Franka, Warszawa: Wydawnictwo Prawnicze 1956.

RADZIK Tadeusz: Lubelska dzielnica zamknięta, Lublin: Wydawnictwo Uniwersytetu Marii CurieSkłodowskiej 1999.

SCHENK Dieter: Hans Frank. Biografia generalnego gubernatora, Kraków: Wydawnictwo Znak 2009.

SIEROCIŃSKA Magdalena: Eksterminacja „niewartościowych rasowo” dzieci polskich robotnic przymusowych na terenie III Rzeszy w świetle postępowań prowadzonych przez Oddziałową Komisję Ścigania Zbrodni przeciwko Narodowi Polskiemu w Poznaniu, [w:] https://ipn.gov.pl/ pl/aktualnosci/587,Eksterminacja-niewartosciowych-rasowo-dzieci-polskich-robotnicprzymusowych-na-t.html [dostęp: 17.03.2018].

THEISS Wiesław: Sieroctwo wojenne polskich dzieci (1939-1945). Zarys problematyki, Przeglad Pedagogiczny 1 (2012), s. 79-95.

WNuK Józef: Polskie dzieci oskarżają, Lublin: Wydawnictwo Lubelskie 1975.

WrZYszZCZ Andrzej, DĄBROwsKi Karol: Das Familienrecht im Generalgouvernement, [w:] Judiciary and Society between Privacy and Publicity. 8th Conference on Legal History in the Baltic Sea Area, 3rd-6th September 2015, red. D. Janicka, Toruń: Wydawnictwo Naukowe Uniwersytetu Mikołaja Kopernika 2016, s. 141-162. 
WRZYSZCZ Andrzej: Hierarchia aktów prawnych wprowadzonych przez okupanta niemieckiego w Generalnym Gubernatorstwie w latach 1939-1945, Studia Iuridica Lublinensia 22 (2014), s. 695-708.

WRZYsZCZ Andrzej: Okupacyjne sądownictwo niemieckie w Generalnym Gubernatorstwie 1939-1945. Organizacja i funkcjonowanie, Lublin: Wydawnictwo Uniwersytetu Marii Curie-Skłodowskiej 2008.

WRZYSZCZ Andrzej: Ustawodawstwo antyżydowskie wprowadzone przez okupanta niemieckiego w Generalnym Gubernatorstwie (1939-1945), [w:] Scientia nihil est quamveritatis imago. Studia ofiarowane Profesorowi Ryszardowi Szczygłowi w siedemdziesięciolecie urodzin, red. A. Sochacka, P. Jusiak, Lublin: Wydawnictwo Uniwersytetu Marii Curie-Skłodowskiej 2014, s. 991-1007.

WrZYszCZ Andrzej: Ustawodawstwo okupacyjne dla dystryktu Galicja 1941-1944, [w:] Studia z historii państwa, prawa i idei, prace dedykowane Profesorowi Janowi Malarczykowi, red. A. Korobowicz, H. Olszewski, Lublin: Wydawnictwo Uniwersytetu Marii Curie-Skłodowskiej 1997, s. $483-500$.

WrZYsZCZ Andrzej: Uwagi o prawie łaski w Generalnym Gubernatorstwie (1939-1945). Podstawy normatywne stosowania prawa łaski w GG, Studia z Dziejów Państwa i Prawa Polskiego t. IX (2006), cz. 2, s. 445-452.

WRZYSZCZ Andrzej: Z problematyki segregacji narodowościowej i rasowej ludności w systemie prawa i sądownictwa niemieckiego Generalnego Gubernatorstwa (1939-1945), [w:] Społeczeństwo a władza. Ustrój, prawo, idee, red. J. Przygodzki, M.J. Ptak, Wrocław: Wydawnictwo Kolonia Limited 2010, s. 791-808.

VENKEN Machteld: Child forced labour: an analysis of ego documents throughout time, European Review of History 22 (2015), z. 2, s. 368-388.

ZAJADŁO Jerzy: Formuła Radbrucha. Filozofia prawa na granicy pozytywizmu prawniczego i prawa natury, Gdańsk: Wydawnictwo Arche 2001.

\section{STATUS PRAWNY DZIECKA W NIEMIECKIM USTAWODAWSTWIE W GENERALNYM GUBERNATORSTWIE (1939-1945)}

\section{Streszczenie}

Przedmiotem artykuły jest analiza statusu prawnego dziecka w niemieckim ustawodawstwie w Generalnym Gubernatorstwie. Autorzy przedstawiają status dziecka na gruncie różnych aktów prawnych wprowadzonych przez niemieckich okupantów w poszczególnych gałęziach prawa. Ochronne funkcje prawa względem dziecka zostały praktycznie w całości złamane w ustawodawstwie niemieckim w Generalnym Gubernatorstwie. Prawodawcy w Generalnym Gubernatorstwie nie prowadzili zaplanowanej i usystematyzowanej działalności ustawodawczej względem dzieci. Wprowadzone przez niemieckich okupantów przepisy dotyczące dzieci odzwierciedlały jednak najważniejsze cele polityki nazistowskiej. W przepisach dotyczących dzieci w Generalnym Gubernatorstwie widoczne są wszystkie cechy prawa nazistowskiego: rasizm, pogwałcenie podstawowych zasad słuszności i sprawiedliwości. Autorzy analizują w artykule wyłącznie sferę normatywną, pomijając działania podejmowane poza sferą normatywną.

Słowa kluczowe: status prawny dziecka; prawo; Generalne Gubernatorstwo; II wojna światowa 


\section{THE LEGAL STATUS OF THE CHILD IN GERMAN LEGISLATION IN THE GENERAL GOVERNMENT (1939-1945)}

\section{S u m m a r y}

The subject of the article is the analysis of the legal status of the child in German legislation in the General Government. The authors present the status of the child on the basis of various legal regulations introduced by German occupiers in different areas of law. Most of the legal principles regarding to the child protection and child rights have been completely broken in German legislation in the General Government. The legislatures in the General Government did not carry out planned and systematic legislative activity towards children. However, the children's regulations introduced by the German occupiers reflected the most important goals of Nazi policy. The regulations regarding to the child in the General Government show all the features of Nazi law: racism, violation of the basic principles of equity and justice. The authors concentrated in the article only on the normative sphere, omitting activities undertaken outside the normative sphere.

Key words: legal status of the child; law; General Government; World War II 